\title{
The Influence of Field Training on Pre-service Teachers' Social Skills for Teaching
}

\author{
Reham Sahlab, Yasmeen Abu Mukh, Naela Mater, Wajeeh Daher* \\ Faculty of Educational Sciences, An-Najah National University, Palestine
}

Received June 9, 2020; Revised July 20, 2020; Accepted August 10, 2020

\section{Cite This Paper in the following Citation Styles}

(a): [1] Reham Sahlab, Yasmeen Abu Mukh, Naela Mater, Wajeeh Daher, "The Influence of Field Training on Pre-service Teachers' Social Skills for Teaching," Universal Journal of Educational Research, Vol. 8, No. 9, pp. 4193-4200, 2020. DOI: 10.13189/ujer.2020.080946.

(b): Reham Sahlab, Yasmeen Abu Mukh, Naela Mater, Wajeeh Daher (2020). The Influence of Field Training on Pre-service Teachers' Social Skills for Teaching. Universal Journal of Educational Research, 8(9), 4193-4200. DOI: 10.13189/ujer.2020.080946.

Copyright $\mathrm{O} 2020$ by authors, all rights reserved. Authors agree that this article remains permanently open access under the terms of the Creative Commons Attribution License 4.0 International License

\begin{abstract}
Field training is valuable for improving pre-service teachers' teaching skills. It bridges the gap between theory and practice in real classroom environment. This study uses phenomenological qualitative approach to investigate the influence of field training courses on social skills in teaching. The study was carried out in the first semester of the 2019-2020 academic year with a total of six pre-service teachers participating in a field course for 10 weeks. The pre-service teachers came from two different colleges of teachers' training. We used purposive sampling to choose the students. After interviewing the participants and videoing their lessons, we transcribed the interviews and observations. We used thematic analysis to code, categorize and find patterns related to the development of social skills for teaching. The research results showed that pre-service teachers who practiced teaching during field training have improved their social skills in teaching as a result of three conditions (1) classroom management, (2) teaching strategies and (3) supervisor's assessment. Pedagogic supervisors need to focus on these three issues in order to provide a fruitful environment for pre-service teachers' professional development.
\end{abstract}

Keywords Pre-Service Teachers, Field Training, Teaching Skills, Social Skills

\section{Introduction}

It is imperative to prepare teachers who can keep abreast with various developments in diverse fields, with knowledge, in terms of appropriate preparation and training as one of the most prominent elements of the educational system [1-4]. In the two academic institutions in which the present research was held, the process of preparing teachers begins before teachers enter the teaching profession through the university's teacher education program which includes a field training course.

Field training course at college level plays a pivotal role in providing a real-world teaching experience for pre-service teachers in a supportive and authentic context [5]. The aim of field training is to shape and strengthen the basic teaching strategies and provide feedback [6]. The process of professional development to become a teacher begins before entering an education program along years of experience in the school [7]. These experiences and related memories form the basis of professional development during teacher education. In field training, pre-service teachers formulate ideas about their abilities from field experiences, and classroom observations [8]. In this study, the influence of field training on social teaching skills is investigated.

Social constructivism has been used as a framework for this study as it offers a great insight on how the practice of field training helps construct knowledge through interacting with classroom teachers and students during the training [9].

\subsection{Research Problem}

Education is a tool for national development to occur. Quality education can only be obtained through 
quality-teachers, as no educational system will increase the quality of its teachers [10]. Previous studies have explored the content and development of student teachers' skill through field training that they receive during the university study stage [7,11-12].

Field training is a pedagogical training course to prepare pre-service teachers to carry out their educational functions very effectively. Pre-service teachers practice the role of teachers to accomplish educational goals in certain educational situations [13]. In spite of the studies in teacher preparation (e.g., [14-15]), few studies were concerned with the role of field training in developing pre-service teachers' social skills in teaching. This study attempts to investigate the influence of pre-service teacher education on the development of their social skills in teaching.

\subsection{Research Question}

What is the influence of field training on pre-service teachers' social skills for teaching?

\section{Literature Review}

To achieve the goal of this study, the authors reviewed three key elements: field training, teaching skills, and social skills.

\subsection{Field Training}

Field training helps students begin to create a clear image of the basics of the teaching profession that would support and sustain them in their future teaching [16]. It is vital for pre-service teachers to build pedagogical and specialty competences, in order to face the demands of the profession, in terms of knowledge of academic subjects and pedagogical skills [17].

Various studies drew attention to the importance of field training in enhancing teaching skills like lesson planning, classroom management, teaching strategies, assessment strategies. Tican and Denis [18] described some of these skills: administrative skills, pedagogical skills, and technological skills. Altan and Ucuncuoglu [19] conducted a study with seven pre-service teachers and found that their lesson planning skills had improved as a result of field training.

Studies have shown that field training improved assessment skills for pre-service teachers [20]. Fan et. al [21] conducted a study that compared between the views of two focus groups of pre-service teachers from the US and china. The results indicated the inclusion of students' effort in using multiple assessment methods and grading during the field training of pre-service teachers focus groups in both the US and China. Koray and Kahraman [22] found that pre-service teachers implemented formative assessment since it had many advantages such as improving efficiency, providing chances to strengthen student's skills and knowledge.

\subsection{Teaching Skills}

Teaching skills in general are related to selecting certain teaching strategies that fit theoretical frameworks, teaching objectives, encourage students' involvement and enhance classroom interaction (e.g., [23-24]). Teaching skills refer to various kinds of processes that are used to share knowledge with students. The main objective of teaching skills is to facilitate student learning [11]. This includes the creation of an environment, where students can get involved in learning in a manner that suits them [12]. Usman, John and Simvyap [10] recommended the need to develop teaching skills for teachers, and emphasized the role of educational institutions and the state in developing teaching skills for teachers and preparing them in an appropriate way. Specifically, field training gives teachers a good chance to use teaching skills that support students in their learning [25].

\subsection{Social Skills}

Social components and processes are used to initiate and maintain positive interactions with other people [26]. Yüksel [27], as in Erdoğan and Çargit [26], defines social skills as learnable, socially acceptable, influential, target-specific, contextual and communication-facilitating behaviors involving observable and unobservable cognitive and affective items that bring positive reactions and prevent negative reactions.

Social skills are learned through observation and imitation and reinforced by positive feedback. Educational processes depend especially on good communication between teachers and students. Research shows that teacher effectiveness is closely related social skills that support students' success and satisfaction [26]. The previous argument indicates the role of field training in educating for social skills in teaching, so the pre-service teachers apply those skills in their future teaching in order to support students' success and satisfaction in their learning.

\subsection{Communication Skills for Teaching}

Field training course should focus on improving the ability of pre-service teachers to express themselves correctly and effectively, whether in a written or an oral form, since the teaching profession requires vitally important communication [28]. Communication skills are defined as the ability to transmit a message by talking or writing [29]. Uygun and Aribas [30] mentioned that communication is a bidirectional interaction process that occurs mutually. Uygun and Aribas [30] enumerated different communication skills such as expressing one's self in verbal and written form, the ability to explain one's opinion, listening, establishing relationships, expressing 
thoughts and feelings, being open-minded, and discussing different perspectives. Okoli [31] stressed that effective teachers communicate with students to engage them and grasp their attention through dynamic delivery of information and appropriate employment of instructional materials and proper gestures.

Effective preparation of pre-service teachers needs close communication between classroom teachers and pre-service teachers, which helps to build an effective learning environment. Through this communication, classroom teachers offer feedback to pre-service teachers with positive tone. This feedback is liable to improve the performance of pre-service teachers by making them fully engaged, as they become aware of their words, the tone of voice, their facial expressions, body posture, and non-verbal communication [32].

Effective preparation of pre-service teachers needs also close communication between classroom teachers and pre-service teachers, which is crucial during field training. Through this communication, supervisors provide performance feedback that assists pre-service teachers to implement proper communications with their students [33]. Moreover, according to Bearwald [34], effective conversation and guidance could be offered by supervisors through asking critical questions, which influences pre-service teachers' performance. Furthermore, supervisors could facilitate a dialog with pre-service teachers for planning lessons, and for using formative assessment to monitor students' performance [35].

\section{Methodology}

A phenomenological approach was adopted for the study as it aims to explore how pre-service teachers understand their social skills in teaching after the implementation of field training course. Following this approach could lead to categorizing the social skills in teaching that were influenced by the field training experience of pre-service teachers.

\subsection{Research Context, Setting and Participants}

As mentioned above, the study is framed by social constructivism context. Pre-service teachers are interacting with students, classroom teachers, and with their supervisors to construct knowledge, and develop attitudes and practices related to the use of social skills in the classroom through this social interaction.

The study was carried out in the first semester of the 2019-2020 academic year with a total of 6 pre-service teachers participating in a field course for 10 weeks. Purposeful sampling was used in this study as it enables researchers to select participants who are providing data more relevant to the studied phenomenon [36]. According to Creswell [37], a phenomenological study should include between 3 and 10 subjects. Following Creswell's recommendation, our target sample for this study would include about 5-6 pre-service teachers that were selected to participate in this phenomenological study.

All the pre-service teachers were in the third year in Khadoorie University and Al-Qasimi Academic College of Education. The participants that volunteered to participate in the research were three pre-service teachers from the Special Education and Arabic Language specialties at Al-Qasemi Academic College of Education and three pre-service teachers from Technology Education specialty at Khadoorie University. The special education and Arabic Language specialties included twenty-five students, while the Technology Education specialty included twenty-eight students. These were the populations that we targeted in the present research.

Table 1 describes the participants in terms of their background variables.

Table 1. Features of the participating pre-service teachers in terms of background variables

\begin{tabular}{|c|c|c|c|c|c|}
\hline Fictive name & Gender & Age & Specialty & Achievement & Institute \\
\hline Rahiq & Female & 22 years & $\begin{array}{c}\text { Special education and } \\
\text { Arabic language }\end{array}$ & Excellent & $\begin{array}{c}\text { Al-Qasimi Academic College of } \\
\text { Education }\end{array}$ \\
\hline Mai & Female & 21 years & $\begin{array}{c}\text { Special education and } \\
\text { Arabic language }\end{array}$ & Excellent & $\begin{array}{c}\text { Al-Qasimi Academic College of } \\
\text { Education }\end{array}$ \\
\hline Roaia & Female & 22 years & $\begin{array}{c}\text { Special education and } \\
\text { Arabic language }\end{array}$ & Good & $\begin{array}{c}\text { Al-Qasimi Academic College of } \\
\text { Education }\end{array}$ \\
\hline Shahd & Female & 22 years & Technology Education & Good & Khadoorie University \\
\hline Salam & Female & 21 years & Technology Education & Good & Khadoorie University \\
\hline Fatima & Female & 22 years & Technology Education & Excellent & Khadoorie University \\
\hline
\end{tabular}




\subsection{Data Collection Tools}

Data was collected through two tools: videoing and interviewing. Below, we describe each one of these tools.

\subsubsection{Videoing}

Third-year college pre-service teachers who participated in field training courses were videoed and then the videos were transcribed. The observation focused on the following topics: actions and behaviors, planning and implementation of goals, questions, strategies, classroom management, social networking, evaluation, tools and teaching aids.

In an effort to establish a sample that would best help gain an understanding of the experiences stated in the research question, the selection of the subjects was purposive in its process [38]. Six lessons which the pre-service teachers conducted at special education schools and regular education schools were videoed and transcribed.

\subsubsection{Interviews:}

The pre-service teachers who participated in the field training course were interviewed after observing their lessons. Semi-structured interviews and classroom observations have been used for data collection. The interviews lasted for about 30 minutes. Seidman [39] explained the aim of the interviews is to explore the influence of field training on the teaching and social skills of student teachers. The interview questions were based on the research question. Examples on these questions are: (1) Describe the usage of different teaching methods during field training, (2) describe your use of teaching aids in the classroom during field training, (3) which teaching skills did you develop during field training if any, and how? (4) which social skills did you develop during field training if any, and how? (5) describe your social interaction with students in school during field training, (6) describe your social interaction with pedagogic supervisor during field training?

The interview protocol consisted of open-ended questions and a series of probing questions that were used to extract more in-depth responses from participants' experience. The participants agreed to record the interviews and the observations. A consent form was signed by the participants. The questions were repeated or, if necessary, reworded, until the interviewer was convinced that the interviewee had fully expressed the thought she had shared. Consideration was given to the fact that the interviewees might not understand the wording of the questions (e.g., metaphors) or perceive different meanings of the questions; not those intended by the interviewer. The interviewees were, therefore, encouraged to ask questions.

\subsection{Data Analysis Tools}

This research presents a phenomenology study as a type of qualitative research that analyses the implementation influence of field training on social skills in teaching. We are describing a situation (field training experience) and how it affected the pre-service social skills in teaching during field training. Interpreters are well qualified to interpret the results. Two of the interpreters are lecturers who supervise pre-service students in field training (the first and second authors) and the third interpreter is a principal who has been monitoring pre-service teachers in her school (the third author).

After interviewing the participants and videoing their lessons, we transcribed the interviews and observations. We used thematic analysis to code, categorize and find patterns related to the development of social skills for teaching. In order to guarantee the trustworthiness of the research analysis, the agreement between judges was used [40]. Two persons separately transcribed $25 \%$ of the transcription and identified the connections between categories and sub-categories. The agreement between judges was .875 which is considered a fair value for educational research. The interviewees were given the interview results and asked to make proposals or comment on the texts.

\section{Findings}

Field training improved the social skills of pre-service teachers, which encouraged the appearance of their direct and efficient communication with students, classroom teachers and college supervisors. Below, we elaborate on each one of the improved social skill for teaching.

\subsection{Communication between the Educational Communities}

The pre-service teachers' communication with the three other educational communities (students, teachers and supervisors) was noticeably improved. Below we elaborate on each communicational type.

\subsubsection{Communication with Classroom Students}

Through field-teaching, pre-service teachers were able to improve their social skills by using positive reinforcement. Observing Shahd in one of her lessons showed that she used verbal reinforcement in the class. Students' answers were usually reinforced by one of the words: excellent, wonderful, beautiful, etc. All these reinforcements had an influence on strengthening the relationship between classroom students and pre-service teachers, which motivated the students to engage actively in the lesson.

\subsubsection{Communication with Classroom Teacher}

Field training has helped pre-service teachers dramatically to improve their social skills by interacting with classroom teachers and building rapport with them. 
Classroom teachers acted as guidance for pre-service teachers. Fatima said during her interview "our classroom teacher was very supportive and played a critical role in developing our social skills, guided us to treat the students nicely and with respect, I learned a lot by observing her how she paid attention and responded to her student's psychological needs. Also, she always offered continuous feedback on how to plan for lessons, to choose the right teaching strategy and to design the right teaching aid".

\subsubsection{Communication with College Supervisor}

It was obvious after interviewing the pre-service teachers that field training helped in improving social skills of the pre-service teachers by interacting and communicating efficiently with their supervisors. The social relationship was based on participation, cooperation, sharing and exchange of ideas to develop pre-service teaching skills. Raheeq said in the interview: "I changed in the way I communicated with my school teacher at the beginning of the field training", also, she said "there was a great and a strong relationship between us and our supervisor, she was directing us, offering help and guidance."

\subsection{Factors Leading to the Development of Communication Skills of the Pre-Service Teachers}

Below, we describe the factors that led to the improvement of the verbal communication with the three educational communities (students, teachers and supervisors): classroom management, teaching strategies and assessment.

\subsubsection{Classroom Management as a Factor for Communication with Students}

Through managing their field-teaching, pre-service teachers were motivated to improve their social skills by using verbal positive reinforcement. When one of the pre-service teachers; Shahed, was asked about her class management skills, she said: "I never imagined what it meant to be in a real classroom environment, practicing teaching. It was hard at the beginning to manage the learning of young children, I needed to try new educational methods to manage the classroom. Gradually I learned that I need to be nice in order to manage the students' learning, that is the way!"

When requested by the interviewer to elaborate, Shahed said: "I learned how to use verbal reinforcement in the class. Students' answers are usually reinforced by a reinforcement word, as excellent, wonderful, beautiful. All these reinforcements strengthened the relationship between me and the students, which helped me improve my management skills of the classroom." The first goal of Shahed was to manage her teaching and her students' learning, where she learned, through her teaching experiences, that this could be done if she increased her positive communication with her students.

Effective lesson planning was one element in the management of the classroom that played a key role in strengthening the communication with students. In planning the lessons, the pre-service teachers took care of the communication with the students in order to inspire and motivate them to be engaged well in the lessons. Fatima said: "Lesson planning was an opportunity to take care of strengthening my communication with the students. This helped me actualize this communication while implementing the lesson."

\subsubsection{Teaching Strategies as a Factor for Communication with Students}

The pre-service teachers found field training fruitful, as this practice helped them to differentiate between teaching strategies like story narration, discussion, cooperative teaching and brainstorming. Variation in teaching strategies helped the pre-service teachers improve their social skills through communication with the students. In one of Raheeq's lessons, she used an interactive dialogue strategy consisting of clear language, non-verbal communication, and the use of gestures and signals to transfer a message repeatedly. Raheeq also said: "I advanced towards using a cooperative teaching strategy, since it is the most appropriate method that helped me to recognize students' personalities, grab their attention, and interact effectively with the subject being taught and the classroom environment, since cooperative teaching contribute to enhance communicate with students, peer and group interaction, through this strategy, helps to understand each other by forgiving, helping, caring and sharing responsibility to accomplish the task."

When a pre-service teacher, Shahed, was asked to describe how the field training helped her improve her social skills in teaching, she answered: "I came to recognize the importance of diversification of teaching methods while I was practicing in the school. I found that lecturing is not enough to reach the goals, so I started to use cooperative teaching and demonstrations while I am practicing. This improved my communication with the students as I found different methods to approach them."

Selection of the teaching aids has also contributed to the communication between the pre-service teachers and school students. It enhanced the interaction of the students with the teacher and with themselves, as well as students' effective involvement. Fatima said: "I believe that teaching aids encourage students to interact. Utilizing interactive teaching aids enhances their interaction with me and with each other verbally and non-verbally." During the observation of one of Raheeq's lessons, she was using cards with legumes and starches pictures to motivate the interaction among her students and with her as she discussed their exploration of the content. 


\subsubsection{Teaching strategies as a factor for communication with classroom teacher}

Effective verbal and non-verbal communication between classroom teacher and pre-service students were mainly based on choosing the appropriate teaching strategy for the classroom that adapts to students' abilities and the taught subject. Effective communication skills between the classroom teacher and pre-service students were manifested through lesson planning including the selection of teaching strategies. During the lesson planning, the pre-service teachers developed their communication with the classroom teachers, including dialogue, ongoing discussions. The communication with the classroom teacher included post-lesson feedback on the pros and cons of the teaching strategy and the aids that have been implemented; one again through dialogue and discussions.

The communication with the classroom teachers included non-verbally elements, as the teachers communicated through gestures and facial expressions while the pre-service teacher was standing in front of the students.

\subsubsection{Teaching Strategies as a Factor for Communication with College Supervisor}

Supervisors offered a great guidance to help pre-service teachers practice and be able to teach the content. A great part of the guidance of the supervisors was for the teaching strategies that would better be implemented in the lessons. In the frame of this guidance, the pre-service teachers developed their communication skills with the pedagogic supervisors, as they started to use different communication channels to do that. Roaia said: "Our communication with the pedagogic supervisor started through the weekly meetings with her, but gradually it extended to more channels as the email, we got to know that each communication channel had its own characteristics as when to use it."

\subsubsection{Assessment as a Factor for Communication with Students, Teachers and the College Supervisor}

The supervisors were responsible to evaluate the pre-service teachers' field training by providing constructive feedback to improve their teaching strategies and communication with the teachers and the students. The Supervisor's role was to enhance and assess these strategies and communication to achieve the educational goals. Doing that, they focused on assessing the pre-service teachers' behavior and conduct in the classroom, including discussion, brainstorming and communication, with the goal to improve the communication between pre-service teachers and the other educational communities. Salam said: "The supervisor made it clear from the beginning that we need to care for interaction with the teachers and students at the training schools. She said we would be assessed for the quality of these interactions, so we needed to take care of this issue in our interactions with the teachers, the students and the supervisor herself."

\section{Discussion and Conclusions}

The aim of this study was to explore the influence of field training on pre-service teachers' social skills in teaching. This research comes in the frame of the learning of pre-service and in-service teachers [e.g. 41-42]. The findings revealed that field training plays a vital role in enhancing these skills, mainly improving their communication skills. Though the six participants had common similarities like high academic standing and age, they came from two different colleges with different specialties: Arabic language and special education and technology education. Field training assisted the pre-service teachers from different specialties in enriching and improving their communication skills, where these skills are the most important for the teacher's work. This consideration of the communication skills for teaching suits the pragmatic-orientation to teaching that defines teaching as being around relationships and communication [43]. It seems that the field training made the pre-service teachers realize what Evertson and Weinstein [44], as in Egeberg, McConney and Price [45], stressed as the function of teachers: "The actions teachers take to create an environment that supports and facilitates both academic and social-emotional learning ... It not only seeks to establish and sustain an orderly environment so students can engage in meaningful academic learning, it also aims to enhance students' social and moral growth." (p. 4) In the present study, this enhancement of social and moral growth came through utilizing communication skills in interacting with the school students.

The field training improved the social skills for teaching of the pre-service teachers, which made them more ready for a classroom culture that nurtures students' learning. In addition to reinforcing an individual's behavior, communication skills are also one of the psychosocial tools in building knowledge according to Vygotsky [46]. The social constructivist theory emphasizes that learning and knowledge take place as the learner interacts socially with another more knowledgeable person. Here the field training enabled different social interactions and communications that are expected to enrich school students' learning experiences.

As demonstrated in this study, the pre-service teachers reported positive changes in their communication skills as a result of their participation in field training program, which they identified as contributing to students' learning. Nair and Ghanaguru [17] argued that pre-service teachers' interaction and collaboration with the experienced teachers is crucial for the preparedness of these pre-service teachers for teaching. This interaction occurred in the field training in the two high-education institutions that we report in the present research. The research results are in line with Timoštšuk, Inge Ugaste, Aino [47] who confirmed that field training is an important period for students to start creating a clear picture of the profession of teachers, which could support them in their future teaching practices. 
Moreover, the pre-service teachers experienced real teaching practices which improved their communication skills and their collegial relationships with classroom teachers and students. This improvement implies their preparedness for the teaching profession [48].

The pre-service teachers' work with the three educational communities (school-students, school-teachers and supervisors) contributed to the development of the social skills of the pre-service teachers. This result indicates that the field training needs to provide rich opportunities for this work in order to facilitate pre-service teachers' development as teachers. Nair and Ghanaguru [17] found that the pre-service teachers were anxious about meeting the expectations of school-teachers, which could be addressed through communication in which three communities are involved: the pre-service teacher, the school-teacher and the pedagogic supervisor. The supervisor could be a mediator between the pre-service teachers and the school-teachers, especially at the beginning of the training that occurs in a new school.

The three conditions that were identified in this study as affecting the pre-service teachers' social skills in teaching were: (1) classroom management, (2) teaching strategies and (3) supervisor's assessment. Pedagogic supervisors need to focus on these three issues in order to provide a fruitful environment for pre-service teachers' professional development.

\section{REFERENCES}

[1] Chitra, D. (2019). Emerging Trends in Teacher Education in India. Excellence in Education Journal, 8 (2), 5-14.

[2] Baris, Y., \& Hasan, A. (2019). Teacher Education in China, Japan and Turkey. Educational Research and Reviews, 14(2), 51-55.

[3] Daher, W., \& Baya'a, N. (2015). Integrating HOTS activities with GeoGebra in pre-service teachers' preparation. International Scholarly and Scientific Research \& Innovation, 9(7), 2441-2444.

[4] Daher, W., Baya'a, N., \& Anabousy, R. (2018). In-service mathematics teachers' integration of ICT as innovative practice. International Journal of Research in Education and Science, 4(2), 534-543.

[5] Durdukoca, Ş. F. (2018). Teacher's views on 'teacher training system in turkey'. European Journal of Education Studies, 4(1), 279-308.

[6] Kumar, R. S., Subramaniam, K., \& Naik, S. (2015). Professional development workshops for in-service mathematics teachers in India. The first sourcebook on Asian research in mathematics education: China, Korea, Singapore, Japan, Malaysia and India, 2, 1631-1654.

[7] Körkkö, M., Kyrö-Ämmälä, O., \& Turunen, T. (2016). Professional development through refection in teacher education. Teaching and Teacher Education, 55, 198-206.
[8] Siwatu, K. O. (2011). Preservice teachers' culturally responsive teaching self-efficacy-forming experiences: A mixed methods study. Journal of Educational Research, 104(5), 360-369.

https://doi.org/10.1080/00220671.2010.487081

[9] Bozkurt, G. (2017). Social constructivism: Does it succeed in reconciling individual cognition with social teaching and learning practices in mathematics? Journal of Education and Practice, 8(3), 210-218.

[10] Usman, I.,John, D., \& Simvyap, W. (2019). Developing Effective Teaching Skills: What Teachers Should Know, Journal of Science, Technology \& Education (JOSTE), $7(1), 34-40$

[11] Rust, F. O. C. (2019). Redesign in teacher education: the roles of teacher educators. European Journal of Teacher Education, 42(4), 523-533.

[12] Gisbert, M., \& Usart, M. (2018). Videomining for the assessment of teacher skills in higher education. Towards Personalized Guidance and Support for Learning, 179-191.

[13] Kumari, S. N., \& Naik, S. P. (2016). Effect of Reflective Teaching Training and Teaching Aptitude on Teaching Skills among Elementary Teacher Trainees. Journal on Educational Psychology, 9(3), 11-23.

[14] Baya'a, N., Daher, W. (2015). The development of college instructors' technological pedagogical and content knowledge. Procedia - Social and Behavioral Sciences, 174, $1166-1175$.

[15] Baya'a, N., Daher, W., \& Anabousy, A. (2019). The development of in-service mathematics teachers' integration of ict in a community of practice: Teaching-in-context theory. International Journal of Emerging Technologies in Learning (iJET), 14(01), 125-139.

[16] Shaughnessy, M., \& Boerst, T. A. (2018). Uncovering the skills that preservice teachers bring to teacher education: The practice of eliciting a student's thinking. Journal of teacher Education, 69(1), 40-55.

[17] Nair, P., \& Ghanaguru, S. (2017). Owning the Classroom: Student Teachers' Experiences and Concerns during Practicum. The English Teacher, 3, 18.

[18] Tican, C., \& Deniz, S. (2019). Pre-service teachers' opinions about the use of 21 st century learner and 21 st century teacher skills. European Journal of Educational Research, 8(1), 181-197.

[19] Altan, E. B., \& Ucuncuoglu, I. (2019). Examining the development of pre-service science teachers' STEM-Focused lesson planning skills. Eurasian Journal of Educational Research, 19(83), 103-124.

[20] Daniels, L. M., \& Poth, C. A. (2017). Relationships between pre-service teachers' conceptions of assessment, approaches to instruction, and assessment: An achievement goal theory perspective. Educational Psychology, 37(7), 835-853.

[21] Fan, X., Johnson, R., Liu, J., Zhang, X., Liu, X., \& Zhang, T. (2019). A comparative study of pre-service teachers' views on ethical issues in classroom assessment in China and the United States. Frontiers of Education in China, 14(2), 309-332.

[22] Koray, Ö., \& Kahraman, E. (2019). Pre-Service Preschool 
Teachers' Opinions about the Formative Assessment. Turkish Online Journal of Educational Technology-TOJET, 18(1), 77-87.

[23] Huang, C.-Y. \& Kuo, S.-H. (2018). Teacher preparation in response to competence-based curriculum reform for k-12 education: National Taiwan University's proposal of inquiry-based and competence-based teacher education. Journal of Research in Education Sciences, 63(4),59-87. doi: 10.6209/JORIES.201812_63(4).0003

[24] $\mathrm{Wu}$, C. S. (2018). Construction and practice of competency-based teacher education. Journal of Research in Education Sciences, 63(4), 261-293. doi:10.6209/JORIES.201812_63(4).0009

[25] Wragg, E.C., (2001). Classroom Teaching Skills, 3rd edition. London: Croom Helm Ltd.

[26] Erdoğan, E., \& Çargit, B. (2018). Comparison of pre-service teachers' social skill levels. Universal Journal of Educational Research, 6(12), 2907-2912. https://doi.org/10.13189/ujer.2018.061225.

[27] Yüksel, G. (2004). Sosyal Beceri Envanteri El Kitab1. Ankara: Asil Yayın Dağıtım

[28] Kavrayici, C. (2020). Communication skills and classroom management: The mediating role of problem solving skills. Journal of Teacher Education and Educators, 9(1), 125-137.

[29] McCroskey, J. C., \& McCroskey, L. L. (1988). Self-report as an approach to measure communication competence. Communication Research Reports, 5(2), 108-113.

[30] Uygun, K., \& Aribas, B. (2020). Examining the relationship between social intelligence levels and communication skills of prospective social studies teachers. Educational policy analysis and strategic research, 15(1),1-22.

[31] Okoli, A. C. (2017). Relating communication competence to teaching effectiveness: implication for teacher education. Journal of Education and Practice, 8(3), $150-154$

[32] Conderman, G., Johnston-Rodriguez, S., \& Hartman, P. (2009). Communicating and Collaborating in Co-Taught Classrooms. Teaching Exceptional Children Plus, 5(5), 5.

[33] Rathel, J. M., Drasgow, E., \& Christle, C. C. (2008). Effects of supervisor performance feedback on increasing preservice teachers' positive communication behaviors with students with emotional and behavioral disorders. Journal of Emotional and Behavioral Disorders, 16(2), 67-77.

[34] Bearwald, R. (2011). It's about the questions. Educational Leadership, 69, 74-77.

[35] Knight, J. (2013). High impact instruction: A framework for great teaching. Thousand Oaks, CA: Corwin.

[36] Merriam, S. (2009). Qualitative research: A guide to design and implementation. Hoboken, NJ: Jossey-Bass (Wiley).

[37] Creswell, J. W. (2007). Qualitative inquiry and research design: Choosing among five approaches (2nd ed.). Thousand Oaks, CA: Sage.

[38] Meiners, J. D. (2016). A phenomenological study of professional and practical changes experienced by teachers involved with action research in a learning community Master's Program. All Theses, Dissertations, and Other Capstone Projects. Paper 587.

[39] Seidman, I. (2006). Interviewing as qualitative research: A guide for researchers in education and the social sciences. Teachers college press.

[40] Denzin N. and Lincoln Y. (Eds.) (2000). Handbook of Qualitative Research. London: Sage Publication Inc.

[41] Sabbah, K., Kobari, S., Ahmad, M. A., \& Daher, W. (2020). The Effect of Education for Future Program on Teachers' Competencies in a Public School. Universal Journal of Educational Research, 8(7), 2890-2897.

[42] Daher, W. (2014). Students' Adoption of Social Networks as Environments for Learning and Teaching: The Case of the Facebook. International Journal of Emerging Technologies in Learning, 9(4).

[43] Naylor, D. A., Campbell-Evans, G., \& Maloney, C. (2015). Learning to teach: What do pre-service teachers report. Australian Journal of Teacher Education, 40(11). http://dx.doi.org/10.14221/ajte.2015v40n11.7

[44] Evertson, C. M., \& Weinstein, C. S. (Eds.). (2006). Handbook of classroom management: Research, practice, and contemporary issues. Mahwah, NJ: Erlbaum.

[45] Egeberg, H. M., McConney, A., \& Price, A. (2016). Classroom management and national professional standards for teachers: a review of the literature on theory and practice. Australian Journal of Teacher Education, 41(7). http://dx.doi.org/10.14221/ajte.2016v41n7.1

[46] Vygotsky, L. (1962). Thought and language (E. Hanf-mann \& G. Vakar, Trans.). Cambridge, MA: MIT Press.

[47] Timoštšuk, I., \& Ugaste, A. (2010). Student teachers' professional identity. Teaching and Teacher Education, 26(8), 1563-1570. https://doi.org/10.1016/j.tate.2010.06.008

[48] Manasia, L., Ianos, M. G., \& Chicioreanu, T. D. (2020). Pre-service teacher preparedness for fostering education for sustainable development: An empirical analysis of central dimensions of teaching readiness. Sustainability, 12(1), 166. 